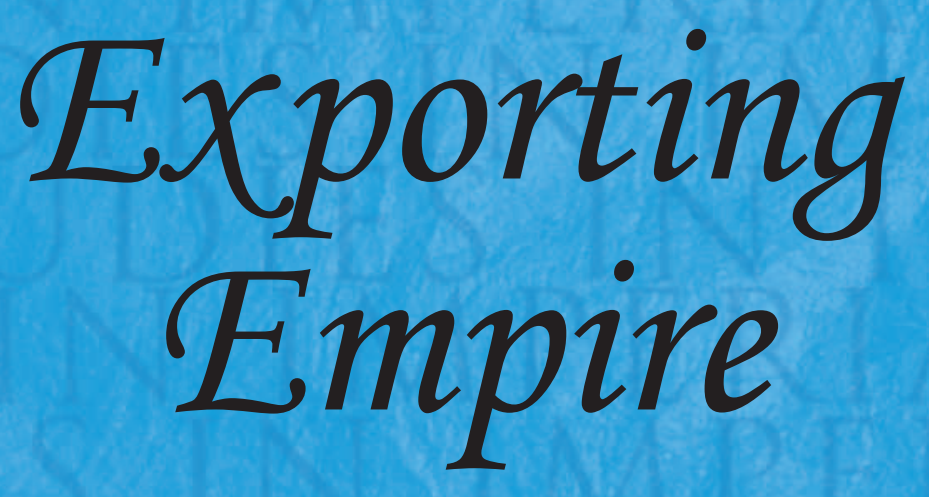

Africa, colonial officials and the construction of the imperial state, c.1900-39

\title{
CHRISTOPHER PRIOR
}

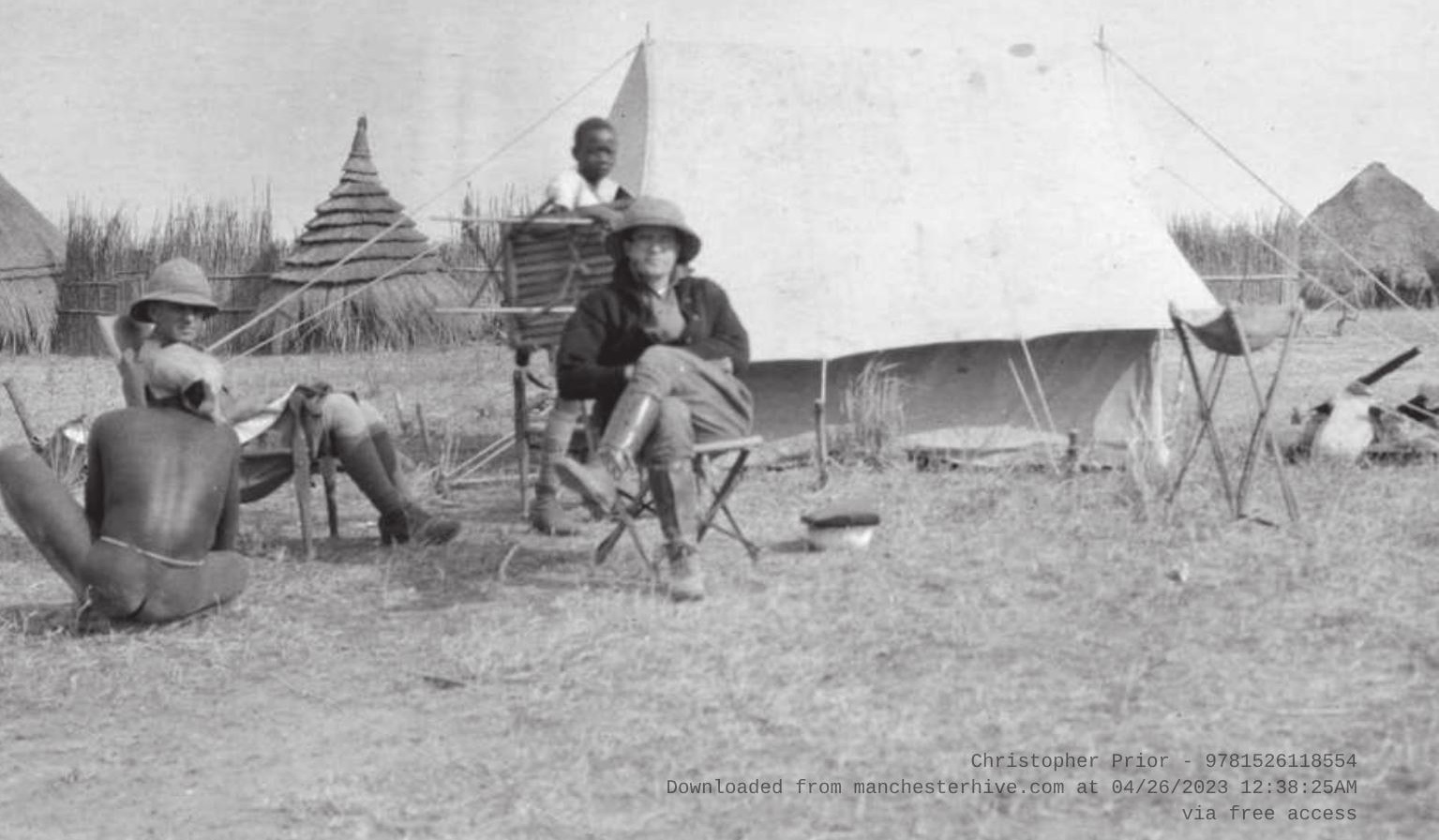




\section{IMPERIALISM}

general editor John M. MacKenzie

When the 'Studies in Imperialism' series was founded by Professor John M. MacKenzie more than thirty years ago, emphasis was laid upon the conviction that 'imperialism as a cultural phenomenon had as significant an effect on the dominant as on the subordinate societies'. With well over a hundred titles now published, this remains the prime concern of the series. Cross-disciplinary work has indeed appeared covering the full spectrum of cultural phenomena, as well as examining aspects of gender and sex, frontiers and law, science and the environment, language and literature, migration and patriotic societies, and much else. Moreover, the series has always wished to present comparative work on European and American imperialism, and particularly welcomes the submission of books in these areas. The fascination with imperialism, in all its aspects, shows no sign of abating, and this series will continue to lead the way in encouraging the widest possible range of studies in the field. Studies in Imperialism is fully organic in its development, always seeking to be at the cutting edge, responding to the latest interests of scholars and the needs of this ever-expanding area of scholarship.

Exporting empire

MANCHESTER 1824

Manchester University Press 


\title{
SELECTED TITLES AVAILABLE IN THE SERIES
}

\author{
WALES AND THE BRITISH OVERSEAS EMPIRE \\ Interactions and influences, 1650-1830 \\ ed. H. V. Bowen
}

IMPERIAL CITIZENSHIP

Empire and the question of belonging

Daniel Gorman

COLONIAL CONNECTIONS, 1815-45

Patronage, the information revolution and colonial government Zoe Laidlaw

REPRESENTING AFRICA

Landscape, exploration and empire in Southern Africa, 1780-1870

John McAleer

ENDING BRITISH RULE IN AFRICA

Writers in a common cause

Carol Polsgrove 


\title{
Exporting empire
}

\section{AFRICA, COLONIAL OFFICIALS AND THE CONSTRUCTION OF THE BRITISH \\ IMPERIAL STATE, c. 1900-1939}

\author{
Christopher Prior
}

MANCHESTER UNIVERSITY PRESS

Manchester 
Copyright (C) Christopher Prior 2013

The right of Christopher Prior to be identified as the author of this work has been asserted by him in accordance with the Copyright, Designs and Patents Act 1988.

Published by MANCHESTER UNIVERSITY PRESS

ALTRINCHAM STREET, MANCHESTER M1 9JA, UK

www.manchesteruniversitypress.co.uk

British Library Cataloguing-in-Publication Data

A catalogue record for this book is available from the British Library

Library of Congress Cataloging-in-Publication Data applied for

ISBN 9780719083686 hardback

First published 2013

The publisher has no responsibility for the persistence or accuracy of URLs for any external or third-party internet websites referred to in this book, and does not guarantee that any content on such websites is, or will remain, accurate or appropriate.

Typeset in Trump Medieval by Koinonia, Manchester 